\title{
Regulated Market in Tripura: For Sustainable Local Governance
}

\author{
Sujoy Hazari ${ }^{1+}$ and Trinankur Dey² \\ ${ }^{1}$ Research Scholar, Faculty of Management and Commerce, the ICFAI University Tripura, Kamalghat, \\ Tripura -799210, India \\ ${ }^{2}$ Assistant Professor, Faculty of Management and Commerce, the ICFAI University Tripura, Kamalghat, \\ Tripura -799210, India
}

\begin{abstract}
The farmers are getting poorer despite the increase in the agricultural GDP. The profitability of agriculture has declined while the risk involved has increased. The changes in the policyenviron ment and the market situation have not benefited the small andmarginalfarmers uniformly. The study attemp ts to project the regulated market of Tripura with different amenities available in the market vicinity. Alto get her 21 markets have been deliberately studied with twentynumbers of respondents fromeach market, and a total 420 numbers of responses are recorded; and a $z$-test has been applied to ascertain the relative importance of the specific variables. The market information, storing, weighing, sorting facilities are significantly affected on the marketing of agricultural produce in regulated markets of Tripura. In contrast, grading and transportationfacilities have beenfound less affected by the regulated market system in Tripura. The first controlled market was created (1964). Following that, three markets were controlled in 1981, and seventeen markets were regulated in 1986. In Tripura, the government has taken several mea sures to establish a controlled market. Despite these measures, there has been no discernible improvement in the state of Tripura's regulated markets.
\end{abstract}

Keywords: Regulated market, Agricultural produce market committee, agricultural market

JEL Codes: A10, A11, D40, G40, L10, M38, Q13
Abbreviation:
APMC: Agricultural produce market committee.
GDP: Gross Domestic Product.
DMI: Directorate of Marketing and Inspection.

+ Corresponding author. Tel.: + 918837042897; E-mail address: sujoyhazari@ iutripura.edu.in 


\section{Introduction}

Good governance is mandatory for a democratic environment and sustainable development. For effective implementation of the pre-programmed developmental activities in the community, delegation of powers, authorizing responsibilities to the local heads can ensure better governance. It is evident in the agricultural sector also where Govt. intervention with a good governance practice influences the agricultural activities of a state. Governance in agriculture refers to the administrative, institutional, and organizational structures and processes within which agricultural services are embedded (Bitzer, 2016 \& Khodary, 2016). The agriculture sector plays an important role in the survival of the rural people. The importance of agriculture in the socio economic fabric of India can be realized from the fact that the livelihood of the majority of the country's population depends on agriculture (Ravi \& Uthaisuryan, 2012).

Regulated Markets have a vital role to play in restructuring the economy of the country. Against this background, any study relating to the working of Regulated Markets would be of much use to the policymakers for effecting improvements in the working of regulated markets and their utilization. Regulated markets are regarded as accountable entities for carrying out all functions related to the selling of outputs, with the general benefit of the forming society and all final customers in mind (Uthayasuriy an \& Kesavan, 2012).

Hence Regulated markets are a measure to assure and remunerative marketing opportunities that hold the key to continued progress in enhancing farm productivity and profitability and help to provide the reasonable price of the farm produce by providing the information of the market. Markets in which business is done under the rules and regulations framed by the statutory market organization representing different sections involved in markets called Regulated Markets (Saikia, 2013).

The aim of establishing a regulated market is not to provide an alternate marketing method but also the primary goal has been to facilitate free and voluntary competition in the private sector to improve its functions where the farmer can trade his produce too many buyers in a controlled market by free and fair bidding. The regulated markets are regarded as responsible entities for carrying out all duties associated with the selling of agricultural produce while having the general interests of the farming community and the final customers in mind (Rehman et al., 2012).

\section{Statement of the problem}

The Indian rural economy presents a picture of exploitation of the rural masses, especially the poorer ones, by the intermediaries or middlemen and proper marketing facilities. These agents take a large portion of the price charged by the final buyer, depriving the farmers to fend for themselves. Many studies revealed that the farmers received far less than their legitimate share in consumers' rupees (Singh \& Pandey, 2005). All these issues contribute to complexity economic viability in terms of availing marketing facilities by the market functionaries for their marketing practice and efficient utilization. The variables which are found to be important in regulated market operation do not perform consistently as well as adequately in all markets. In Tripura, there are a large number of regulated markets where marketing facilities are not at par in comparison to the standard regulated market norms. Hence this study attempted to show the performances of marketing facilities in the regulated markets of Tripura.

\section{Objective \& Hypotheses of the Study}

This paper attempts to study the governance as well as the performance of the marketing facilities of the regulated market in Tripura. below:

This study embarks with six numbers of hypotheses on the basis of six valuables which are mentioned 
$\mathrm{H}_{11}$ : Regulated market and its operation significantly affected by market information facility.

$\mathrm{H}_{12}$ : Regulated market mechanism significantly affected by storing facility.

$\mathrm{H}_{13}$ : Regulated market mechanism significantly affected by weighing facility.

$\mathrm{H}_{14}$ : Regulated market mechanism significantly affected by the sorting facility.

$\mathrm{H}_{15}$ : Regulated market mechanism significantly affected by Grading facility.

$\mathrm{H}_{16}$ : Regulated market mechanism significantly affected by Transportation facility.

\section{Methodology}

To study the governance of the regulated market in Tripura, all twenty-one numbers of the regulated market have been considered. The study is based on primary and secondary data from the selected area. Secondary data was collected from different published research papers and unpublished Government reports. Furthermore, the primary data was collected for 2019-20 from the different marketing functionaries by personal interview through a structured interview schedule. The variables which have been deemed to be considered concerning the well-functioning of the regulated market are spotted viz. market information facility, storing, weighing, sorting, grading, transportation facility, etc. Questions like how a regulated market should run with all required amenities, what are the required physical facilities with which a regulated market should have etc., have been attempted to address. Twenty numbers of respondents from each market and a total 420 numbers of responses are recorded and a $\mathrm{z}$-test has been applied to ascertain the relative importance of the specific variables. To compare an observed proportion to a theoretical one, a oneproportion z-test is used.

$$
Z=\frac{\left|\bar{x}_{1}-\bar{x}_{2}\right|}{\sigma \sqrt{\left(\frac{1}{n_{1}}+\frac{1}{n_{2}}\right)}} \sim N(0,1)
$$

Where $\overline{\mathrm{x}}_{1}, \overline{\mathrm{x}}_{2}$ is the mean of positive response $\left(\mathrm{n}_{1}\right) \&$ negative response $\left(\mathrm{n}_{2}\right)$ respectively, and $\sigma$ is the common standard deviation. $\mathrm{H}_{1}$ is acceptable if the estimated value of $\mathrm{Z}>$ the table value of $\mathrm{Z}$ is at a $5 \%$ level of significance.

Table No 1: List of Regulated Markets in Tripura

\begin{tabular}{|c|c|c|}
\hline Sl. No & Name of the District & Name of the Regulated Markets \\
\hline 1. & \multirow{2}{*}{ West Tripura } & Mohanpur Agri. Produce Reg. Market \\
\hline 2. & & Champaknagar Agri. Produce Reg. Market \\
\hline 3. & \multirow{4}{*}{ Sipahijala } & Bishalgarh Agri. Produce Reg. Market \\
\hline 4. & & Melaghar Agri. Produce Reg. Market \\
\hline 5. & & Jampuijala Agri. Produce Reg. Market \\
\hline 6. & & Sonamura Agri. Produce Reg. Market \\
\hline 7. & \multirow{2}{*}{ Gomati Tripura } & Garjee Agri. Produce Reg. Market \\
\hline 8. & & Natunbazaar Agri. Produce Reg. Market \\
\hline 9. & \multirow{4}{*}{ South Tripura } & Santirbazar Agri. Produce Reg. Market \\
\hline 10. & & Barpathari Agri. Produce Reg. Market \\
\hline 11. & & Kalashi Agri. Produce Reg. Market \\
\hline 12. & & Silacharri Agri. Produce Reg. Market \\
\hline
\end{tabular}




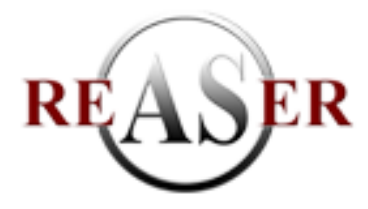

ISSN: $2247-6172$

Review of Applied Socio- Economic Research

(Volume 22, Issue 2/2021), pp. 68 - 77

URL: http://www.reaser.eu e-mail: editors@reaser.eu

\begin{tabular}{|c|c|c|}
\hline 13. & \multirow{3}{*}{ Khowai } & Teliamura Agri. Produce Reg. Market \\
\hline 14. & & Kalyanpur Agri. Produce Reg. Market \\
\hline 15. & & Bachaibari Agri. Produce Reg. Market \\
\hline 16. & \multirow{3}{*}{ Dhalai } & Chawmanu Agri. Produce Reg. Market \\
\hline 17. & & Gandachharra Agri. Produce Reg. Market \\
\hline 18. & & Kulai Agri. Produce Reg. Market \\
\hline 19. & Unakoti & Pabiachharra Agri. Produce Reg. Market \\
\hline 20. & \multirow{2}{*}{ NorthTripura } & Panisagar Agri. Produce Reg. Market \\
\hline 21. & & Dasda Agri. Produce Reg. Market \\
\hline
\end{tabular}

Source: Economic Review of Tripura 2018-19

\section{Results and discussions}

\section{Agricultural Marketing in North-East Region:}

In most of the rural markets, facilities are either not available at all or not adequate. The primary markets in Assam, Meghalaya, and Tripura do not even have basic infrastructural facilities and are mere meeting places for buyers and sellers. By and large, these markets are owned and managed by local bodies which rarely pay any attention to their development. Communication/transport and storage facilities, which are critical components of infrastructure for the expansion of agricultural commerce, are woefully lacking. In rural locations and in primary marketplaces, storage facilities are either non-existent or inadequate. Such amenities are essentially non-existent in Mizoram and Arunachal Pradesh. Storage facilities are large "katcha" in Assam, Manipur, and Tripura. In a considerable number of main marketplaces in Meghalaya, only "pucca" storage facilities are provided. Sorting, grading, and standardizing, packing, and post - harvest treatments, among other functions, are not typically used in post-harvest handling. All of these characteristics have an influence on storage shelf life and long-distance transit (DMI, 2020).

Table no 2: Distribution of Wholesale Assembling Primary and Regulated Markets in NER

\begin{tabular}{|c|c|c|c|c|c|c|c|}
\hline $\begin{array}{c}\text { SI. } \\
\text { No. }\end{array}$ & State & $\begin{array}{c}\text { No. of } \\
\text { Wholesale } \\
\text { Markets }\end{array}$ & $\begin{array}{c}\text { No. of Rural } \\
\text { Periodic } \\
\text { Markets }\end{array}$ & Total & $\begin{array}{c}\text { No. of Principal } \\
\text { Regulated } \\
\text { Markets }\end{array}$ & $\begin{array}{c}\text { No. of } \\
\text { Sub- } \\
\text { yard }\end{array}$ & Total \\
\hline 1 & Assam & 172 & 650 & $\begin{array}{c}822 \\
(43.24)\end{array}$ & 16 & 19 & 35 \\
$(60.34)$
\end{tabular}

Source: Directorate of Marketing and Inspection, Ministry of Agriculture, Govt. of India, 2020 
Table 2 indicates the distribution of Wholesale Assembling Primary and Regulated Markets in the NorthEast Region, where it was observed that Assam holds 43.24 percent of wholesale and rural periodic markets whereas Tripura enjoys the second position with 33.26 percent, followed by other North-Eastern states. In the case of regulated markets, Assam holds the first position with 60.34 percent, followed by Tripura (36.21 percent) and Meghalaya (3.45). In both cases, Tripura holds a satisfactory position in the wholesale assembling primary and regulated Markets. It indicates the market mechanism involved in the regulatory framework has been performing well.

\section{Status of Regulated Market in Tripura:}

Market Regulation in Tripura-Progress in India, market regulation was implemented under the Agriculture Produce Markets Act to regulate the selling and purchase of agricultural products and creates equal competition conditions. The Directorate of Marketing and Inspection provides states with the appropriate advice and assistance in developing and enforcing legislation. Almost all Indian states, including Tripura, have passed market regulation legislation. In Tripura, the State Government enacts the following acts and rules in connection with the establishment of regulated markets (Chakraborty, 2009 \& Mallik, 2019). The acts and rules for regulated markets of Tripura are as follows:

1) The Tripura Agriculture produces Markets Act, 1980

2) The Tripura Agricultural Produce markets (Amendment) Act, 1983

3) The Tripura Agriculture Produce Markets (Administration) Rules, 1985

4) The Tripura Agricultural Produce markets (Second Amendment) Act, 2007

The Agriculture Produce Markets Act of 1980 in Tripura includes provisions for the establishment of controlled markets and the formation of a Market Committee to better regulate goods, sales, storage, and other aspects of listed agricultural produce. Following that, the Tripura Agriculture Produce Markets (Administration) Rules 1985 were enacted to improve market regulations and production. The Tripura Agriculture Produce Markets Act was amended for the first time in 1983 in the state. The amendment was made with the express purpose of creating a Market Board at the state level to coordinate and supervise the market committee's functions. In 2007, the Tripura Agriculture Produce Markets Act was amended for the second time. The Tripura Agricultural Produce Markets (Second Amendment) Act, 2007, made suitable provisions in connection with special markets and special commodities markets, contract farming, the establishment of consumer/farmer markets, and so on, but no amendment has been made for Tripura's regulated markets since 2007.

In Bishalgarh, the first controlled market was created (1964). Following that, three markets were controlled in 1981, and seventeen markets were regulated in 1986. There hasn't been a controlled market in Tripura since 1986. There are currently 21 regulated markets serving farmers across Tripura. Because of a lack of adequate funding from the federal and state governments, regulated markets have not progressed significantly, and a large portion of agricultural markets continue to operate outside of the framework of regulated markets. Aside from that, the accreditation of controlled markets in Tripura varies greatly depending on the five-year plan. The first regulated market in Tripura comes under the act during the third five-year plan, three numbers of a regulated market in Tripura comes under act at sixth five-year plan and maximum i.e., seventeen numbers of a regulated market in Tripura comes under act at the seventh five-year plan.

The efficiency of Regulated Markets in uplifting the economic standard of farmers, therefore it is reflected in their proper utilization by farmers for deriving economic benefits. A higher degree of utilization would lead the farming community to a higher standard of living. Agriculture is one of the most critical aspects of Tripura's economy. However, the gains are not reaching the agricultural population, and one of agriculture's major issues is the promotion of its products. As a result, marketing control has become an important part of state policy for developing the agricultural marketing system. However, market regulation in the state of Tripura is moving at a glacial pace (Report of Director of Marketing, 2007-08). 
ISSN: $2247-6172$

Review of Applied Socio- Economic Research

(Volume 22, Issue 2/2021),pp. 68 - 77

URL: http://www.reaser.eu

e-mail: editors@reaser.eu

Table No 3: Progress of Regulation of Markets in Tripura

\begin{tabular}{|c|c|c|c|c|}
\hline $\begin{array}{l}\text { Sl. } \\
\text { No. }\end{array}$ & $\begin{array}{l}\text { Year of } \\
\text { regulations }\end{array}$ & Regulated Markets & $\begin{array}{l}\text { No of } \\
\text { markets }\end{array}$ & Five-year plan \\
\hline 1 & 1964 & Bishalgarh Agri. Produce Reg. Market & 1 & Third five-year plan \\
\hline 2 & \multirow{3}{*}{1981} & Melaghar Agri. Produce Reg. Market & \multirow{3}{*}{3} & \multirow{3}{*}{ Sixth five-year plan } \\
\hline 3 & & $\begin{array}{l}\text { Santirbazar Agri. Produce Reg. } \\
\text { Market }\end{array}$ & & \\
\hline 4 & & Teliamura Agri. Produce Reg. Market & & \\
\hline 5 & \multirow{17}{*}{1986} & Mohanpur Agri. Produce Reg. Market & \multirow{17}{*}{17} & \multirow{17}{*}{$\begin{array}{l}\text { Seventh five-year } \\
\text { plan }\end{array}$} \\
\hline 6 & & $\begin{array}{l}\text { Champaknagar Agri. Produce Reg. } \\
\text { Market }\end{array}$ & & \\
\hline 7 & & Jampuijala Agri. Produce Reg. Market & & \\
\hline 8 & & Sonamura Agri. Produce Reg. Market & & \\
\hline 9 & & Garjee Agri. Produce Reg. Market & & \\
\hline 10 & & $\begin{array}{l}\text { Natunbazaar Agri. Produce Reg. } \\
\text { Market }\end{array}$ & & \\
\hline 11 & & Barpathari Agri. Produce Reg. Market & & \\
\hline 12 & & Kalashi Agri. Produce Reg. Market & & \\
\hline 13 & & Silacharri Agri. Produce Reg. Market & & \\
\hline 14 & & Kalyanpur Agri. Produce Reg. Market & & \\
\hline 15 & & Bachaibari Agri. Produce Reg. Market & & \\
\hline 16 & & $\begin{array}{l}\text { Chawmanu Agri. Produce Reg. } \\
\text { Market }\end{array}$ & & \\
\hline 17 & & $\begin{array}{l}\text { Gandachharra Agri. Produce Reg. } \\
\text { Market }\end{array}$ & & \\
\hline 18 & & Kulai Agri. Produce Reg. Market & & \\
\hline 19 & & $\begin{array}{l}\text { Pabiachharra Agri. Produce Reg. } \\
\text { Market }\end{array}$ & & \\
\hline 20 & & Panisagar Agri. Produce Reg. Market & & \\
\hline 21 & & Dasda Agri. Produce Reg. Market & & \\
\hline
\end{tabular}

Source: Author compilation

According to table 4, marketing information, inadequate storing, weighing, sorting, grading, and transportation facility respectively impact on 63.33 percent, 72.83 percent, 63.10 percent, 56.90 percent, 46.90 percent, and 44.29 percent market functionaries over all the selected regulated market of Tripura.

Table No 4: Distribution of the market functionary's opinion in respect to the different marketing facilities.

$(\mathrm{n}=420)$

\begin{tabular}{|r|l|c|c|c|c|c|c|}
\hline $\begin{array}{c}\text { S1. } \\
\text { No. }\end{array}$ & Regulated Markets & $\begin{array}{c}\text { Market } \\
\text { information } \\
\text { facility } \\
\text { affected }\end{array}$ & $\begin{array}{c}\text { Storing } \\
\text { facility } \\
\text { affected }\end{array}$ & $\begin{array}{c}\text { Weighing } \\
\text { facility } \\
\text { affected }\end{array}$ & $\begin{array}{c}\text { Sorting } \\
\text { facility } \\
\text { affected }\end{array}$ & $\begin{array}{c}\text { Grading } \\
\text { facility } \\
\text { affected }\end{array}$ & $\begin{array}{c}\text { Transportation } \\
\text { facility } \\
\text { affected }\end{array}$ \\
\hline 1. & $\begin{array}{l}\text { Mohanpur Agri. } \\
\text { Produce Reg. } \\
\text { Market }\end{array}$ & 16 & 15 & 8 & 11 & 8 & 11 \\
\hline 2. & $\begin{array}{l}\text { Champaknagar } \\
\text { Agri. Produce Reg. }\end{array}$ & 12 & 19 & 11 & 9 & 9 & 9 \\
\hline
\end{tabular}


ISSN: $2247-6172$

Review of Applied Socio- Economic Research

(Volume 22, Issue 2/2021),pp.68-77

URL: http://www.reaser.eu e-mail: editors@ @reaser.eu

\begin{tabular}{|c|c|c|c|c|c|c|c|}
\hline & Market & & & & & & \\
\hline 3. & $\begin{array}{l}\text { Bishalgarh Agri. } \\
\text { Produce Reg. } \\
\text { Market }\end{array}$ & 11 & 14 & 12 & 10 & 14 & 7 \\
\hline 4. & $\begin{array}{l}\text { Melaghar Agri. } \\
\text { Produce Reg. } \\
\text { Market }\end{array}$ & 13 & 16 & 18 & 11 & 7 & 7 \\
\hline 5. & $\begin{array}{l}\text { Jampuijala Agri. } \\
\text { Produce Reg. } \\
\text { Market }\end{array}$ & 15 & 18 & 12 & 12 & 15 & 9 \\
\hline 6. & $\begin{array}{l}\text { Sonamura Agri. } \\
\text { Produce Reg. } \\
\text { Market }\end{array}$ & 12 & 12 & 10 & 8 & 12 & 5 \\
\hline 7. & $\begin{array}{l}\text { Garjee Agri. } \\
\text { Produce Reg. } \\
\text { Market }\end{array}$ & 14 & 15 & 11 & 9 & 11 & 8 \\
\hline 8. & $\begin{array}{l}\text { Natunbazaar Agri. } \\
\text { Produce Reg. } \\
\text { Market }\end{array}$ & 13 & 14 & 12 & 7 & 8 & 8 \\
\hline 9. & $\begin{array}{l}\text { Santirbazar Agri. } \\
\text { Produce Reg. } \\
\text { Market }\end{array}$ & 15 & 15 & 12 & 11 & 7 & 7 \\
\hline 10. & $\begin{array}{l}\text { Barpathari Agri. } \\
\text { Produce Reg. } \\
\text { Market }\end{array}$ & 17 & 15 & 17 & 16 & 9 & 9 \\
\hline 11. & $\begin{array}{l}\text { Kalashi Agri. } \\
\text { Produce Reg. } \\
\text { Market }\end{array}$ & 12 & 9 & 13 & 18 & 10 & 10 \\
\hline 12. & $\begin{array}{l}\text { Silacharri Agri. } \\
\text { Produce Reg. } \\
\text { Market }\end{array}$ & 11 & 10 & 15 & 11 & 6 & 8 \\
\hline 13. & $\begin{array}{l}\text { Teliamura Agri. } \\
\text { Produce Reg. } \\
\text { Market }\end{array}$ & 9 & 15 & 16 & 10 & 8 & 9 \\
\hline 14. & $\begin{array}{l}\text { Kalyanpur Agri. } \\
\text { Produce Reg. } \\
\text { Market }\end{array}$ & 13 & 17 & 11 & 8 & 7 & 11 \\
\hline 15. & $\begin{array}{l}\text { Bachaibari Agri. } \\
\text { Produce Reg. } \\
\text { Market }\end{array}$ & 14 & 19 & 13 & 13 & 12 & 6 \\
\hline 16. & $\begin{array}{l}\text { Chawmanu Agri. } \\
\text { Produce Reg. } \\
\text { Market }\end{array}$ & 14 & 18 & 14 & 14 & 11 & 12 \\
\hline 17. & $\begin{array}{l}\text { Gandachharra Agri. } \\
\text { Produce Reg. } \\
\text { Market }\end{array}$ & 12 & 14 & 11 & 12 & 12 & 9 \\
\hline 18. & $\begin{array}{l}\text { Kulai Agri. } \\
\text { Produce Reg. }\end{array}$ & 13 & 15 & 14 & 13 & 5 & 11 \\
\hline
\end{tabular}


ISSN: $2247-6172$

Review of Applied Socio- Economic Research

(Volume 22, Issue 2/2021),pp. 68 - 77

URL: http://www.reaser.eu e-mail: editors@ @reaser.eu

\begin{tabular}{|c|l|c|c|c|c|c|c|}
\hline & Market & & & & & & \\
\hline 19. & $\begin{array}{l}\text { Pabiachharra Agri. } \\
\text { Produce Reg. } \\
\text { Market }\end{array}$ & 12 & 12 & 11 & 15 & 9 & 9 \\
\hline 20. & $\begin{array}{l}\text { Panisagar Agri. } \\
\text { Produce Reg. } \\
\text { Market }\end{array}$ & 9 & 11 & 14 & 10 & 8 & 12 \\
\hline 21. & $\begin{array}{l}\text { Dasda Agri. } \\
\text { Produce Reg. } \\
\text { Market }\end{array}$ & $\begin{array}{c}266 \\
(63.33)\end{array}$ & $\begin{array}{c}306 \\
(72.86)\end{array}$ & $\begin{array}{c}265 \\
(63.10)\end{array}$ & $\begin{array}{c}239 \\
(56.90)\end{array}$ & $\begin{array}{c}197 \\
(46.90)\end{array}$ & $\begin{array}{c}186 \\
(44.29)\end{array}$ \\
\hline Total affected opinion
\end{tabular}

Note: Figures in parentheses indicate the per cent (\%.)

Source: Author compilation

\section{Hypothesis Testing}

Data have been collected from different market and market functionaries through questionnaires and the following test of hypothesis has been shown with the collected data.

Table No 5: Marketing Facilities in Different Regulated Market (Z-Test table of Significance)

\begin{tabular}{|c|l|c|c|c|c|c|c|c|c|}
\hline \multirow{2}{*}{$\begin{array}{c}\text { SI } \\
\text { no. }\end{array}$} & \multirow{2}{*}{$\begin{array}{c}\text { Marketing } \\
\text { Facilities }\end{array}$} & \multicolumn{2}{|c|}{$\begin{array}{c}\text { Sample } \\
\text { Mean }\end{array}$} & \multicolumn{2}{|c|}{$\begin{array}{c}\text { Sample } \\
\text { Size }\end{array}$} & $\begin{array}{c}\text { Standard } \\
\text { Deviation }\end{array}$ & $\begin{array}{c}\text { Test } \\
\text { Score }\end{array}$ & $\begin{array}{c}\text { Level of } \\
\text { Significance }\end{array}$ & \multirow{2}{*}{ Results } \\
\cline { 2 - 7 } & $\overline{\mathbf{x}}_{\mathbf{1}}$ & $\overline{\mathbf{x}}_{\mathbf{2}}$ & $\mathbf{n}_{1}$ & $\mathbf{n}_{\mathbf{2}}$ & $\boldsymbol{\sigma}$ & $\mathbf{Z}$ & $\mathbf{5 \%}$ & \\
\hline 1 & $\begin{array}{l}\text { Market } \\
\text { information } \\
\text { facility }\end{array}$ & 12.66 & 7.33 & 266 & 154 & 2.17 & 24.20 & & \multirow{2}{*}{$\mathrm{H}_{11 \text { accepted }}$} \\
\hline 2 & Storing facility & 14.57 & 5.42 & 306 & 114 & 2.76 & 30.11 & \multirow{2}{*}{1.96} & $\mathrm{H}_{12 \text { accepted }}$ \\
\hline 3 & $\begin{array}{l}\text { Weighing } \\
\text { facility }\end{array}$ & 12.61 & 7.38 & 265 & 155 & 2.45 & 21.06 & & $\mathrm{H}_{13}$ accepted \\
\hline 4 & Sorting facility & 11.38 & 8.61 & 239 & 181 & 2.74 & 10.20 & & $\mathrm{H}_{14}$ accepted \\
\hline 5 & Grading facility & 9.38 & 10.61 & 197 & 223 & 2.59 & -04.87 & & $\mathrm{H}_{15}$ rejected \\
\hline 6 & $\begin{array}{l}\text { Transportation } \\
\text { facility }\end{array}$ & 8.85 & 11.14 & 186 & 234 & 1.87 & -12.39 & & $\mathrm{H}_{16}$ rejected \\
\hline
\end{tabular}

\section{Inferences:}

After the z test analysis, the following inferences could be drawn:

i. It has been observed that the regulated market and its operation significantly affect market information facilities.

ii. There is a profound effect of regulated market mechanism on storing facility of the agri-produce.

iii. Regulated market mechanism immensely affects weighing facility.

iv. The sorting facility is affected by a regulated market mechanism.

v. The regulated market mechanism has been found less influential on grading facilities available in the market, and it is found not significant.

vi. Even it has been observed that transportation facilities also does not significantly affect by the regulated market mechanism.

The results of $\mathrm{Z}$ test table of significance, explain that the variables like market information, storing, weighing, sorting facilities are found to be significantly affected on the marketing of agricultural produce in 
regulated markets of Tripura. In contrast, grading and transportation facilities have been found less affected by the regulated market system of Tripura. This reflects that the transportation system well connects all the regulated markets; even also grading facility is not at all a popularized technique in the regulated market as the market functionaries are not exporting perishable products like fruits and vegetables.

\section{Conclusions}

The Government of Tripura enacted the Agricultural Market Produce Act to provide better regulations for the buying and sale of agricultural produce, as well as the establishment of regulated markets in the state, which could contribute to the establishment of good governance. In North-East India, Assam enjoys the fir st position, and Tripura holds second in wholesale and rural periodic markets. In terms of regulated markets, Assam stands first, followed by Tripura and Meghalaya. In Tripura, the first regulated market was created (1964) during the third five-year plan. Following that, three markets were controlled in 1981 at the sixth fiveyear plan, and seventeen markets were regulated in 1986. There hasn't been a controlled market in Tripura since 1986 at the seventh five-year plan. This stipulates that the performance of regulated market governance is gradually increasing towards sustainable development. The hypothesis was accepted for the variables like market information, storing, weighing, sorting facilities and found significantly affected the marketing of agricultural produce in regulated markets of Tripura. In contrast, grading and transportation facilities are not affected by the regulated market system of Tripura. In Tripura, the government has taken several measures to establish a regulated market. The study's goal was to examine the regulatory market of Tripura and its market functionaries. It was observed that the governance and performance of the regulated market's marketing facilities are satisfactory and operating well. Government should emphasize this sector to guarantee a smooth governance and better performance of the regulated market and marketing facilities in due course of time.

\section{Recommendations for Policy formation}

Variables like information, storing, weighing, sorting facilities are found to be significantly affected in the market operations. Hence, it is suggested to develop and upgrade these cited facilities in the market area so that market functionaries can indulge more benefits out of them. However, it is observed that the marker functionaries are not adopting the grading practice; as a result, the impact of a regulated market mechanism on the grading facility available in the market has been assessed to be insignificant. Therefore, it is strongly suggested that grading facilities should be widely adopted to facilitate product assortment in all regulated marketplaces. Electronic portals on market information systems may be a new feature that can accelerate the marketing information to market functionaries in the regulated markets. The study also recommends regular supervision and surveillance by the market committee so as to facilitate the smooth functioning of the marketing practices.

\section{References}

Bitzer, V., Wennink, B., \& Steenhuijsen Piters, B. (2016). The governance of agricultural extension systems (No. 1 ). Sustainable Economic Development \& Gender. https://www.kit.nl/wp-content/uploads/2018/08/Thegovernance-of-agricultural-ex tension-systems.pdf

Economic Review of Tripura. (2020)

Khodary, Y. (2016). Governance Assessment of the Agricultural Sector in Egypt Agricultural Extension and Cooperation. CARE International in Egypt, 1-127. https://www.care.at/wpcontent/uploads/2017/05/Governance-Assessment-of-the-Agricultural-Sector-in-Egypt English.pdf

Mallik, R. (2019). Performance of Agricultural Regulated Markets in Tripura-A Quest for Rapid Development. International Journal of Recent Technology and Engineering, 8(2S11), 3219-3228. https://doi.org/10.35940/ijrte.b1421.0982s1119

Ravi, S., \& Uthaiyasuriyan, K. (2012). Regulated Market-an Overview. Indian Journal of Applied Research, 1(10), 2325. https://doi.org/10.36106/ijar 
ISSN: $2247-6172$

Review of Applied Socio- Economic Research

(Volume 22, Issue 2/2021), pp. 68 - 77

URL: http://www.reaser.eu e-mail: editors@ reaser.eu

Rehman, S.-U., Selvaraj, M., \& Ibrahim, M. S. (2012). Indian Agricultural Marketing- A Review. A sian Journal of Agriculture and Rural Development, $2(1)$ 69-75.

https://citeseerx.ist.psu.edu/viewdoc/download?doi=10.1.1.1068.458\&rep=rep1\&type=pdf

Report of Director (Marketing). (2007-08). A Comprehensive Planfor Developments of Markets in Tripu ra. Dep tt of Agriculture, Govt. of Tripura.

Saikia, B. (2013). Agricultural Regulated Markets in Assam : An Overview. Social Science Journal of Gargaon College, 7. https://gargaoncollege.org/pub more/8.pdf

Singh, A. K., \& Pandey, S. (2005). Ruralmarketing: Indianperspective. New Age International. https://www.educba.com/z-test-statistics-formula/

https://www.statology.org/one-proportion-z-test-calculator/

https://www.statology.org/one-proportion-z-test-calculator/

Manuscript received: 11.06 .2021

Manuscript received in revised form: 30.09.2021

Manuscript accepted: 01.10.2021 